\title{
Otomatisasi Interpretasi Data terhadap Bukti Perpajakan Digital
}

\author{
Irvan Iswandi ${ }^{1 *}$ \\ ${ }^{1}$ Institut Agama Islam Az-Zaytun, Indramayu, Jawa Barat, Indonesia \\ ${ }^{1}$ irvan.iswandi10@gmail.com \\ * corresponding author
}

\section{ARTICLE INFO}

\section{Article history}

Received 2020-02-10

Revised 2020-06-25

Accepted 2020-06-25

\section{Keywords}

automation, interpretation, digital taxation

\begin{abstract}
The automatic recognition model of digital taxation evidence is seen as one of the important mechanisms in organizations to determine effectiveness in organizational decision making and control. This effectiveness is influenced by the ability of the system to identify and group entity data. Constraints encountered in the introduction of data occur due to the physical condition of tax evidence that is not good, so it requires more time and results in a lack of precision of the interpretation produced by the system.

The effectiveness of the recognition system performance is improved through determining the right steps in grouping entities automatically. This automation capability encompasses the various stages that exist, namely in recognizing transactions, extracting information in them and grouping them appropriately.

This study presents computerized steps in the form of an automation model for interpreting data, both in terms of transaction recognition, extraction and then grouping the entities found in evidence of withholding income tax Article 23 digitally. The main step taken in achieving this is through a basic analysis of the evidence based on the interpretation of the text. Simulations performed on several pieces of evidence show that the process of automation has the potential to increase effectiveness and reduce errors, when compared to manual processes.
\end{abstract}

\section{PENDAHULUAN}

Pajak adalah sumber pendapatan negara yang paling kritis dan dikenakan berdasarkan ketentuan hukum dan peraturan yang berlaku [Anggia, 2019]. Pemanfaatan pajak digital akan meningkatkan interaksi dan transparansi antara otoritas penagihan pajak versus para pembayar pajak. Salah satu alasan mengapa kepatuhan pajak memberatkan adalah karena akses yang buruk ke peraturan pajak. Sebagian besar wajib pajak sering mengeluh bahwa sebagian besar peraturannya tidak jelas dan sulit dipahami [Al Karaawy, 2018].

Relevansi masalah yang disebabkan oleh hasil analisis penggunaan teknologi digital modern dalam praktik administrasi perpajakan cukup tinggi. Teknologi canggih terus berkembang dan berkontribusi pada modernisasi perpajakan. Telah banyak dilakukan penelitian dengan tujuan untuk mengamati kemungkinan teknologi digital untuk organisasi proses administrasi pajak dan transformasinya. Integrasi teknologi canggih memungkinkan untuk memberikan kemudahan dalam administrasi pajak. Penilaian penerapan teknologi terbaru diizinkan untuk mengidentifikasi faktorfaktor tertentu yang mempengaruhi efisiensi proses administrasi perpajakan [Nazarov, 2019].

Teknik-teknik dalam melakukan otomatisasi terhadap interpretasi data tekstual berkembang dengan cukup pesat dalam beberapa tahun ini. Otomatisasi dilakukan untuk mendapatkan pemahaman terhadap suatu informasi. Pemahaman informasi yang dimaksud dapat berupa ekstraksi terhadap entitas dan dapat juga berupa pembentukan kesimpulan. Proses ekstraksi dapat dilakukan berdasarkan fitur yang dirancang sebelumnya atau dengan menggunakan algoritma pembelajaran untuk menentukan entitas atau teks dengan nilai tertinggi sebagai hasil keluarannya (Lizhen Liu, dkk. 2017). Penelitian ini memberikan usulan model otomatisasi terhadap interpretasi data bukti perpajakan digital. 
Dalam domain informatika, perpajakan menjadi salah satu daerah yang menerima banyak perhatian karena perannya yang dominan dalam perusahaan. Perpajakan memiliki peran yang sangat penting dalam menentukan langkah-langkah yang diambil oleh manajemen perusahaan. Kecepatan dan ketepatan dalam penyajian informasi yang berkaitan dengan perpajakan sangat diperlukan bagi pengambilan keputusan oleh pihak manajemen. Otomatisasi interpretasi data dalam perpajakan digital memainkan peranan penting dalam mempercepat proses pengolahan data.

Model struktur pencatatan terhadap bukti perpajakan digital yang diusulkan dalam penelitian ini dilakukan dengan berdasarkan bukti yang telah ditransformasikan ke dalam bentuk teks. Penelitian ini melakukan interpretasi secara otomatis terhadap bukti perpajakan digital. Berdasarkan Kamus Besar Bahasa Indonesia, interpretasi memiliki arti pemberian kesan, pendapat atau pandangan teoritis terhadap sesuatu; tafsiran, menginterpretasikan berarti menafsirkan. Data yang dimaksud dalam penelitian ini berupa teks yang terdapat dalam bukti perpajakan digital yang dijadikan sebagai bahan untuk dilakukan interpretasi terhadapnya sehingga memiliki makna yang jelas yang digunakan dalam pencatatan pajak.

Proses interpretasi data terhadap bukti perpajakan digital dilakukan dengan model simulasi deterministik. Model deterministik merupakan model matematis dimana hasil dapat ditentukan secara tepat melalui perancangan kejadian (Gernot Kubin, 1988). Hal ini dilakukan dengan alasan bahwa keluaran yang dihasilkan dalam usulan penelitian ini bersifat pasti dan bukan random. Keluaran yang diinginkan adalah berbentuk hasil identifikasi tekstual yang dijadikan sebagai dasar pencatatan pajak.

Pendekatan penyelesaian yang digunakan dalam penelitian ini berdasarkan pada pendekatan secara ontologi. Pendekatan ontologi merupakan metode untuk menggambarkan konsep knowledge dalam sebuah domain, yang berisi tipe, properti, dan hubungan konsep-konsep dalam sebuah domain (C.K.Lee, dkk, 2006).

\section{METODE PENELITIAN}

Penelitian ini bertujuan untuk mengembangkan otomatisasi interpretasi terhadap bukti perpajakan digital, baik dalam hal pengenalan transaksi, ekstraksi dan kemudian melakukan pengelompokkan terhadap entitas yang dikenali berdasarkan Natural Language Processing. Langkah utama yang dilakukan dalam pencapaian tersebut melalui analisa dasar terhadap bukti perpajakan digital berdasarkan interpretasi bahasa alami.

Metodologi penelitian yang digunakan untuk menyelesaikan permasalahan di atas, adalah dengan menerapkan aturan pengenalan tata bahasa terhadap input text, dikenal sebagai parsing, dan juga menentukan struktur dari suatu kalimat. Teks yang dimasukkan ke dalam sistem berdasarkan bukti perpajakan digital. Kemudian untuk menghasilkan representasi makna internal terhadap bukti perpajakan digital, maka teks yang dimasukkan ke dalam sistem akan dibandingkan dengan konsep yang relevan dalam basis pengetahuan yang telah disiapkan berdasarkan prinsip pajak yang umum.

Tahapan berikutnya adalah melakukan klasifikasi secara otomatis yang dilakukan oleh sistem berdasarkan hasil pembandingan terhadap teks yang dimasukkan dengan basis pengetahuan. Proses klasifikasi ini akan menentukan jenis entitas yang terkait dengan transaksi perpajakan yang terjadi. Dan pada akhirnya, akan dihasilkan suatu pencatatan atau perekaman terhadap transaksi perpajakan secara otomatis ke dalam sistem, yang akan dijadikan sebagai dasar dalam kalkulasi pajak.

\section{HASIL DAN PEMBAHASAN}

Pemecahan masalah yang telah diurai di atas, dilakukan dengan cara membuat suatu model otomatisasi terhadap interpretasi dari masukan (input) dalam sistem identifikasi. Kemampuan otomatisasi ini melingkupi berbagai tahapan yang ada, yaitu dalam mengenali entitas dalam bukti perpajakan digital, mengekstraksi informasi didalamnya dan mengelompokkannya dengan tepat. Langkah utama yang dilakukan dalam pencapaian tersebut melalui analisa dasar terhadap transaksi berdasarkan interpretasi kata-kata dari bahasa alami. 


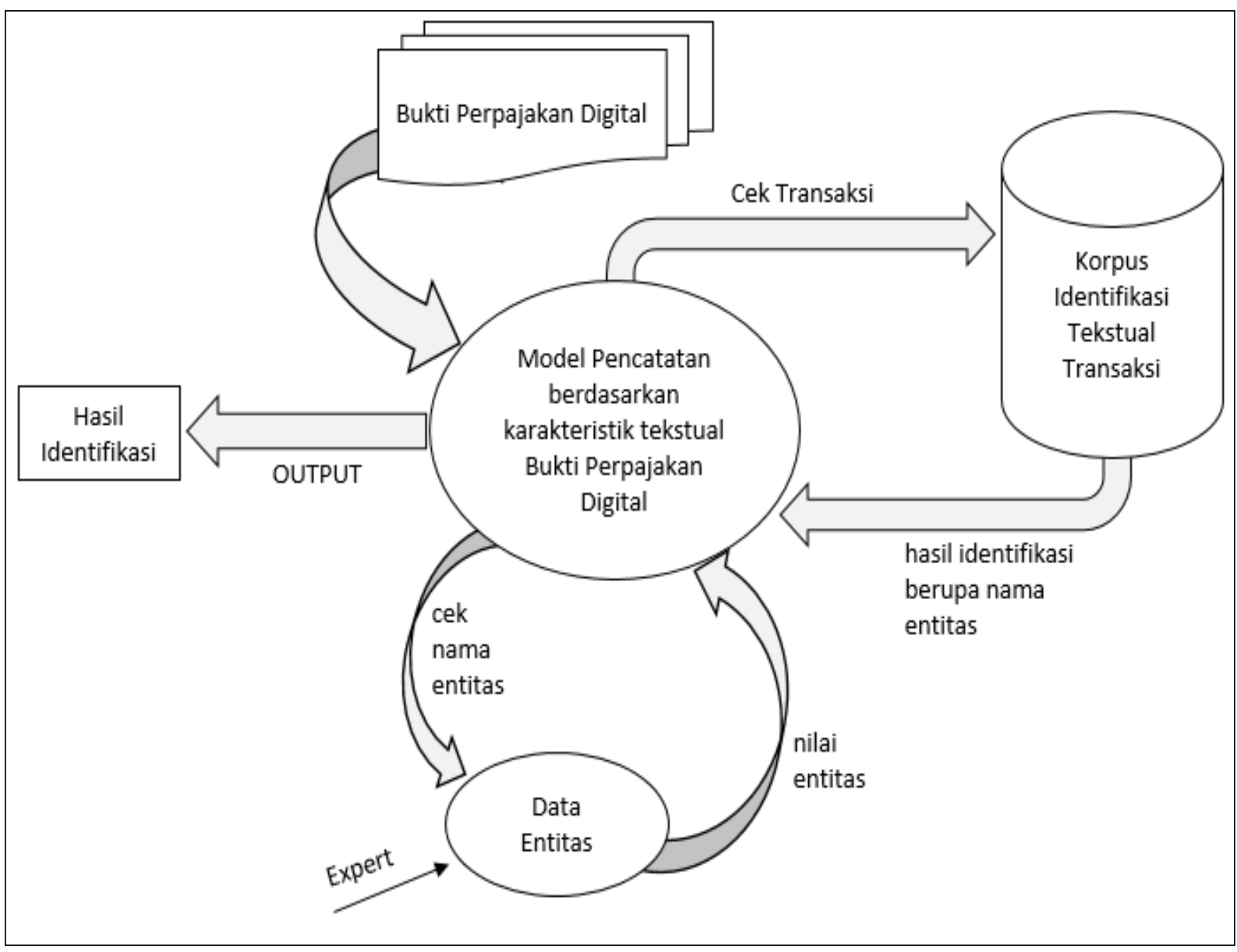

Gambar 1. Model Otomatisasi Interpretasi Bukti Perpajakan Digital

Berikut ini diuraikan mengenai proses otomatisasi interpretasi seperti terlihat pada gambar 1 . Pada gambar 1, diuraikan mengenai proses yang dilakukan dalam menentukan interpretasi terhadap masukan bukti perpajakan digital. Proses otomatisasi interpretasi terhadap bukti perpajakan digital dimulai dari pengenalan terhadap bukti perpajakan digital. Bukti perpajakan digital merupakan suatu dokumen yang digunakan untuk mendokumentasikan transaksi dan juga sebagai alat pertanggung jawaban transaksi. Bukti transaksi tersebut dianalisa terlebih dahulu untuk menentukan keabsahan dan kebenarannya.

Setelah dilakukan analisa terhadap bukti transaksi, kemudian dilakukan masukan transaksi yang terjadi dalam bentuk bahasa alami. Bahasa alami yang dimasukkan ke dalam sistem, diolah oleh model. Model ini memiliki modul-modul analisa, ekstraksi dan interpretasi terhadap bahasa alami yang dimasukkan. Modul-modul tersebut yang terus dikembangkan sehingga menampilkan hasil yang maksimal.

Model ini juga memerlukan data pengetahuan yang didapatkan dari expert yang dimasukkan ke dalam sistem. Data tersebut dijadikan sebagai salah satu dasar klasifikasi terhadap teks yang dimasukkan ke dalam model. Adapun hasil akhir dari model ini adalah berbentuk hasil identifikasi setiap entitas yang telah ditentukan untuk dikenali. Proses yang dilakukan oleh model ini memiliki hambatan ketika bukti perpajakan digital yang dijadikan sebagai bahan analisa telah mengalami beberapa kerusakan secara fisik. Hal ini dapat mengakibatkan kesalahan interpretasi terhadap bukti perpajakan digital tersebut. 


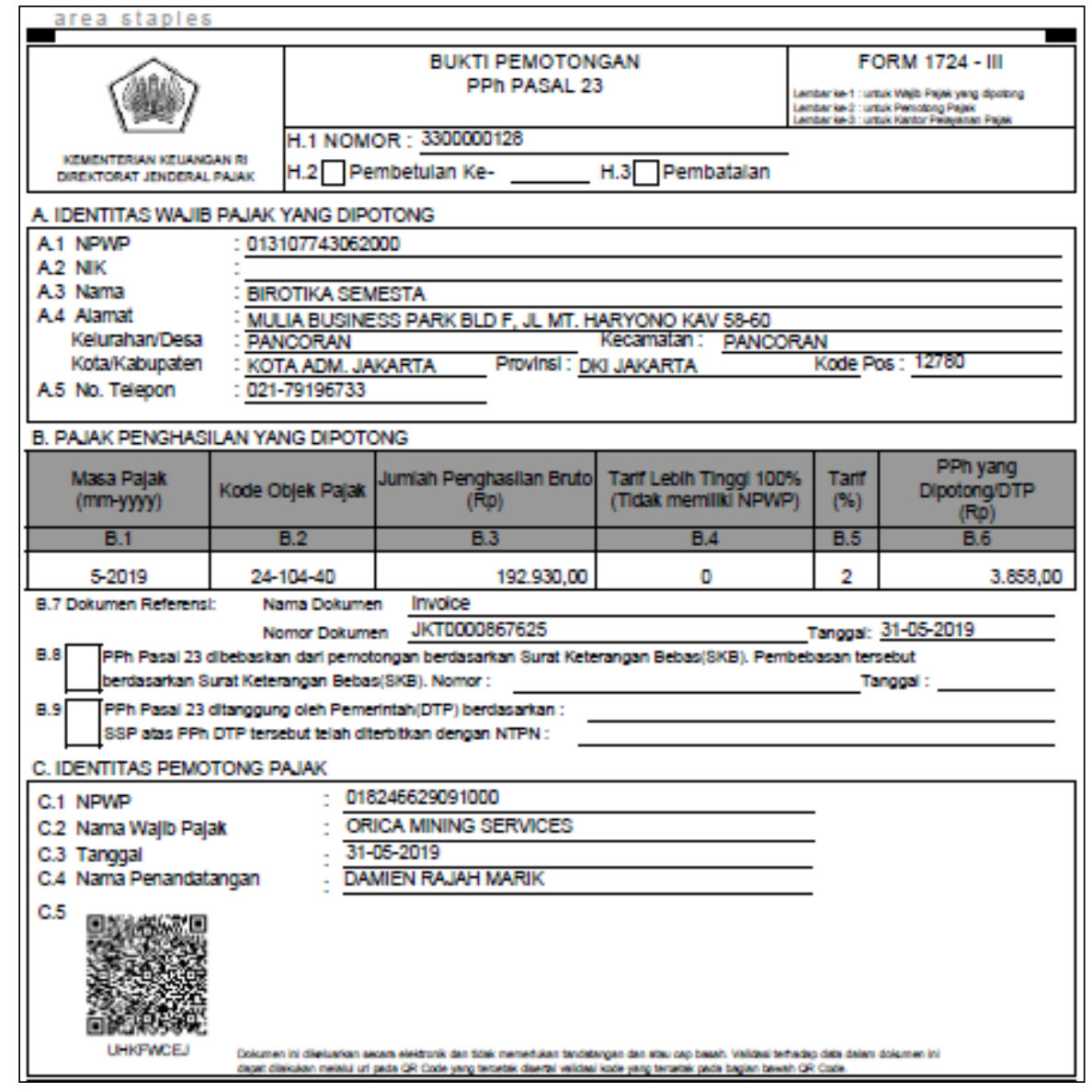

Gambar 2. Contoh Bukti Perpajakan Digital

Sebagai contoh, pada gambar 2 ditampilkan bukti perpajakan digital, yaitu Bukti Pemotongan PPh Pasal 23 yang sudah dalam bentuk digital, baik dalam bentuk file pdf atau image. Bukti Pemotongan PPh Pasal 23 tersebut dimasukkan ke dalam sistem untuk dilakukan interpretasi secara otomatis terhadap entitas-entitas yang terdapat di dalamnya. Adapun entitas-entitas yang dianalisa adalah entitas yang diperlukan dalam pencatatan bagi perusahaan.

Bukti Pemotongan digital tersebut akan ditransformasi ke dalam bentuk teks secara otomatis oleh sistem. Lalu teks akan secara otomatis pula dimasukkan ke dalam sistem. Teks yang dimasukkan ke dalam sistem akan dianalisa berdasarkan metode parsing yang telah dibuat. Dari hasil sementara yang telah berhasil dilakukan, sistem mampu mengklasifikasikan teks dan mengenali makna dari teks tersebut. Hasil sementara yang telah mampu dikenali oleh sistem terhadap Bukti Pemotongan PPh Pasal 23 pada gambar 2 adalah seperti yang ditunjukkan pada tabel I berikut ini :

Tabel I. Hasil pengenalan teks

\begin{tabular}{|c|l|l|}
\hline No & \multicolumn{1}{|c|}{ Deskripsi (Entitas) } & \multicolumn{1}{c|}{ Nilai } \\
\hline 1 & Nomor Bukti Potong & 3300000128 \\
\hline 2 & Tanggal Bukti Potong & $31-05-2019$ \\
\hline 3 & NPWP Pemotong Pajak & 018246629091000 \\
\hline 4 & Nama WP & ORICA MINING SERVICES \\
\hline 5 & Jumlah Penghasilan Bruto & $192.930,00$ \\
\hline 6 & Jumlah PPh Yang Dipotong & $3.858,00$ \\
\hline 7 & Jenis Penghasilan & $24-104-40$ \\
\hline
\end{tabular}


Langkah selanjutnya yang dilakukan oleh sistem adalah menampilkan hasil identifikasi terhadap Bukti Pemotongan PPh Pasal 23. Hasil identifikasi secara otomatis tersebut dilakukan oleh sistem dengan lebih cepat dibandingkan bila dilakukan secara manual. Kemudian, nilai dari setiap entitas dapat disimpan ke dalam basis data untuk digunakan sesuai keperluan bagi perusahaan.

\section{KESIMPULAN}

Proses pencatatan terhadap Bukti Pemotongan PPh Pasal 23 terkadang terhambat karena lambatnya proses yang dilakukan secara manual. Hal ini akan mengakibatkan keterlambatan dalam proses penyajian laporan rekapitulasi perpajakan. Untuk mengatasi hal tersebut, maka dapat dilakukan dengan membuat otomatisasi pengenalan terhadap Bukti Pemotongan PPh Pasal 23 berdasarkan bahasa alami yang diinput ke dalam sistem.

Penelitian ini telah menyajikan proses yang dapat dilakukan untuk mengotomatisasi proses pengenalan dan pengelompokkan beberapa entitas dalam Bukti Pemotongan PPh Pasal 23. Proses otomatisasi ini dilakukan dengan menterjemahkan bahasa alami yang dimasukkan ke dalam sistem sehingga dihasilkan pengenalan dan klasifikasi terhadap entitas yang ditemui. Hal ini terbukti telah mempercepat proses pencatatan terhadap Bukti Pemotongan PPh Pasal 23 jika dibandingkan dengan proses secara manual.

\section{Ucapan Terima Kasih}

Penulis mengucapkan terima kasih yang sebesar-besarnya kepada Yang Berhormat Rektor Institut Agama Islam Az-Zaytun Indonesia, Bapak Imam Prawoto, S.E., M.B.A. yang telah memberikan dukungan sepenuhnya atas penelitian ini sehingga dapat memberikan hasil yang diharapkan secara maksimal.

\section{DAFTAR PUSTAKA}

Al Karaawy Najim Abd Aliwie, "The Impact of Making Tax Digital Application on The Accounting Costs", Academy of Accounting and Financial Studies Journal, Volume 22, Issue 3, 2018.

Anggia Putri, 2019, “The Influence of International Tax Policy on The Indonesian Tax Law", Yuridika: Volume 35 No 2, May 2020.

C. K. Lee, S. Foo dan G. Goh, "On the Concept and Types of Knowledge," Journal of Information \& Knowledge Management, vol. 5, pp. 151-163, 2006.

Chandana Surabhi M, 2013, "Natural Language Processing Future", Proceedings of International Conference on Optical Imaging Sensor and Security, Coimbatore, Tamil Nadu, India, July 2-3, 2013.

F.Siasar djahantighi, M.Norouzifard, S.H.Davarpanah, M.H.Shenassa, 2008, “Using Natural Language Processing in Order to Create SQL Queries", Proceedings of the International Conference on Computer and Communication Engineering.

Gernot Kubin, "Stochastic versus deterministic concepts in adaptive systems design", IEEE, 1988.

H. Sajady, M. Dastgir, H. Hashem Nejad, M. S., Juli / Desember 2008, "Evaluation Of The Effectiveness Of Accounting Information Systems", International Journal of Information Science and Technology, Volume 6.

Imran Sarwar Bajwa, M. Abbas Choudhary, 2006, "Natural Language Processing based automated system for UML diagrams generation", 18th National Computer Conference, Saudi Computer Society.

Irvan Iswandi, Iping Supriana Suwardi, "Otomatisasi Interpretasi Data dalam Sistem Informasi Akuntansi", Seminar Nasional Informatika dan Aplikasinya (SNIA) 2013, Bandung, 18 Desember 2013 
Kimin Seo, Jaemin Choi, Yong-seok Choi, Dong-chan Lee, Sangjin Lee, June 8-11, 2009, "Research about Extracting and Analyzing Accounting Data of Company to Detect Financial Fraud", Isi 2009, Richardson, TX, USA

Lizhen Liu, Wandi Du, Hanshi Wang, Wei Song, "Automatic Summarization in Chinese Product Reviews", Telkomnika, Vol.15, No.1, March 2017.

Mary Dee Harris, Ph.D, 1991, "Natural Language Interface to a Corporate Cash Management System", IEEE.

Mohd Azwan B. Mohamad, Abd Manan Ahmad, 2002, "Flight Schedule Query System Based on Natural Language Processing", Student Conference on Research and Development Proceedings, Shah Alam, Malaysia.

Metin Allahverdi, 2011, “A General Model of Accounting Information Systems”, IEEE.

Nazarov M. A., "Digital Transformation of Tax Administration”, ISCDTE, 2019.

Siamak Nejadhosseini Soudani, 2012, "The Usefulness of an Accounting Information System for Effective Organizational Performance", International Journal of Economics and Finance, Vol.4, No.5, May 2012.

Zsuzsanna Toth, 2012, "The Current Role Of Accounting Information Systems", Club of Economics in Miskolc, TMP Vol.8, Nr.1, pp.91-95. 